\title{
KINETICS OF YTTRIUM DISSOLUTION FROM WASTE CERAMIC DUST
}

\author{
Srećko R. Stopića ${ }^{a}$ Bernd G. Friedrich ${ }^{b}$ \\ RWTH Aachen University, Faculty of Georesources \\ and Materials Engineering, IME Process Metallurgy \\ and Metal Recycling, Aachen, Germany \\ a e-mail: sstopic@ime-aachen.de, \\ ORCID iD: iDhttp://orcid.org/0000-0002-1752-5378 \\ b e-mail: bfriedrich@ime-aachen.de
}

FIELD: Chemical Technology

DOI: 10.5937/vojtehg64-8668

ARTICLE TYPE: Original Scientific Article

ARTICLE LANGUAGE: English

\section{Summary:}

Yttrium is a silvery transition metal and has similar chemical properties to lanthanoids. Because of this similarity, yttrium belongs to rare earth elements. Ytttrium and yttrium oxide are mostly used in fluoroscent lamps, production of electrodes, in electronic filters, lasers, superconductors and as additives in various materials to improve their properties. Yttrium is mainly recovered from the minerals monazite $\left[(\mathrm{Ce}, \mathrm{La}, \mathrm{Th}, \mathrm{Nd}, \mathrm{Y}) \mathrm{PO}_{4}\right]$ and xenotime $\mathrm{YPO}_{4}$. The presence of radioactive elements such as thorium and uranium in the ore makes it difficult to separate yttrium oxide from primary raw materials. Environmental regulations are getting stricter every year, thus increasing the risk of lacking the supply of rare earths. Therefore, recovery of yttrium oxide from secondary sources such as red mud, coatings from ceramic industry and phosphors is extremely important. The main aim of this study is to examine the yttrium dissolution kinetics from waste ceramic dust using hydrochloric acid.

Key words: yttrium, recycling, hydrometallurgy, ceramics.

\section{Introduction}

Yttrium is always found with rare earth elements in minerals. Rare earth metals are increasingly establishing themselves as crucial industrial materials, with unique applications in numerous fields (Kim

\footnotetext{
* ACKNOWLEDGMENT: I would like to thank M.Sc. Marc Spinnräker for his work on selective dissolution of yttrium from waste materials at the IME Process Metallurgy and Metal Recycling of the RWTH Aachen University in Germany.
} 
and Osseo-Asare, 2012, pp.67-78). The feasibility of using yttrium oxide as a crucial material or a coating for induction melting of titanium is widely used in metallurgy. The native source of yttrium can be found in hard rocks and placer sands. Hard rock deposits are mined by open pit and underground methods. The aim of physical beneficiation is increasing the necessary mineral content by exploiting some physical processes. During physical beneficiation, accompanying minerals such as ilmenite, rutile, zircon, magnetite, and quartz are separated, which results in the formation of a concentrate with an increased content of rare earth elements. During a chemical treatment of a concentrate, rare earths are separated from impurities, especially thorium and uranium from minerals. This is accomplished by attacking minerals with some leaching agents. The process parameters such as temperature, pressure, chemical type and concentration of the leaching agent differ in accordance with the mineral type. In monazite applications, sodium hydroxide and sulfuric acid are mostly used as leaching agents. In the dissolution process, rare earth elements and thorium are precipitated in the hydroxide and sulfate forms. In the alkali application, the formed rare hydroxides are dissolved in the next step with either hydrochloric or nitric acid where thorium is not soluble (Sung-Don, 2010, pp.70-76). Cold water is used to dissolve rare earth sulfates in an acid treatment. The dissolution of xenotime is similar to monazite digestion. It requires more concentrated leaching agents and higher process conditions. During the subsequent separation, individual rare earth elements are separated from their mixtures. Fractional crystallization and solvent extraction (Amaral and Morais, 2010, pp.498-503) are mostly used for this separation.

Yttrium is generally recovered from monazite or xenotime minerals via an acid and an alkaline route as shown in Figure 1.

A full process for the recovery of rare earth elements from a composite ore containing rare earth elements, including a monazite mineral group and an apatite mineral, contains the pre-leaching of the composite ore with an acid in order to substantialy dissolve the apatite mineral into the leach liquor and precipitate rare earth elements from the pre-leach liquor (Mackowski et al, 2009, US Patent $0272230 \mathrm{~A} 1)$. An analysis of a combined hydro-pyrometallurgical route for the processing of ores resulting in the production of rare earth elements was investigated using the Chuktukon ores in East Siberia in Russia (Kuzmin et al., 2012, pp.1-16). The main aim of this work by Kuzmin was to develop methods of unlocking rare earth elements in refractory ores and to study some methods for their further chemical processing. 


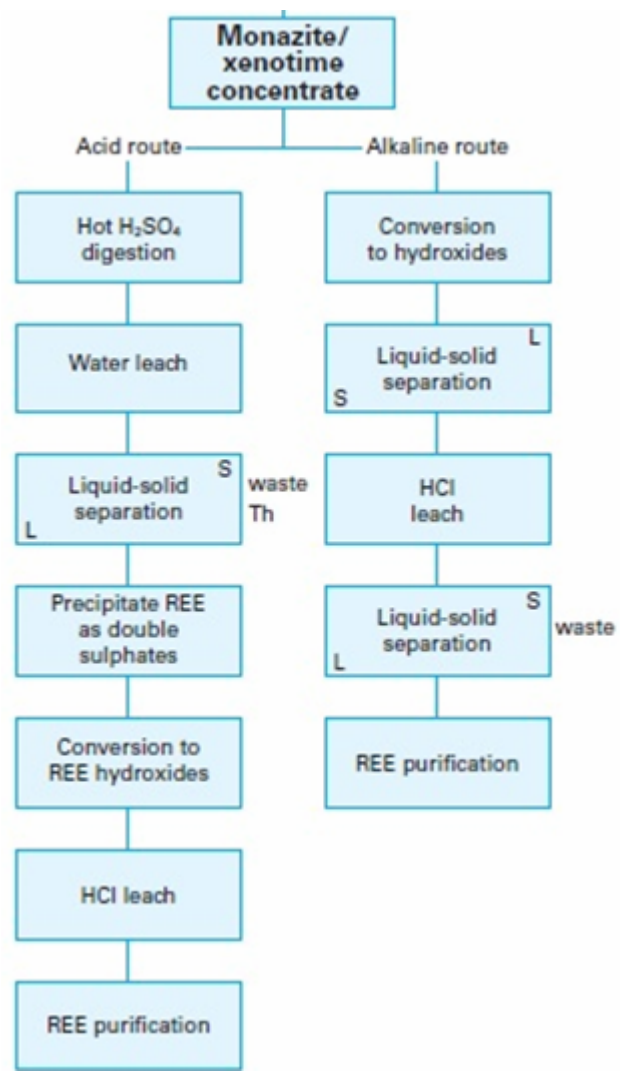

Figure 1 - Flow diagram of the dissolution of monazite and xenotime Puc. 1 - Диаграмма процесса растворения моноцита и ксенотима Slika 1 - Dijagram toka rastvaranja monazita i ksenotima

The precipitation of a cleaned solution with oxalic acid and the thermal decomposition of a formed metal oxalate after filtration with its previous drying represent the final steps in the production of rare earth oxides (Ibrahim and El-Hussaini, 2007, pp.11-17).

The importance of yttrium and other rare earth elements is increasing in the transition to green economy because of their essential role in permanent magnets, lamp phosphors, catalysts, rechargeable batteries, etc. Due to the fact that China presently produces more than $90 \%$ of the global REE output and has an increasingly tight export quota, the rest of the world is in the risk of lacking REE supply. Because of the absence of economical and/or operational primary deposits on their territories, many European countries have to be included into the recycling of REEs from pre-consumer scrap, industrial residues and REE-containing End-of-Life products. Despite considerable, mostly lab- 
scale research effort to recycle REEs, less than $1 \%$ of REEs were recycled by 2011 . This is mainly due to inefficient collection, technological problems and, especially, a lack of incentives. A drastic improvement in the recycling of REEs is, therefore, an absolute demand. This can only be realized by developing efficient, fully integrated recycling routes, which can take advantage of the rich REE recycling literature. In Table 1, secondary materials for REEs are listed (Binnemans, 2013, pp.1-22.)

Table 1 - REE-containing streams for recycling Tabela 1 - Vrste otpada kao izvori retke zemlje za recikliranje Таблица 1 - Виды отходов как источник сырья для рециклирования

\begin{tabular}{|l|l|l|}
\hline \multicolumn{1}{|c|}{ Materials stream \& application } & \multicolumn{1}{|c|}{ REEs } & \multicolumn{1}{|c|}{$\begin{array}{c}\text { Present / future } \\
\text { contribution }\end{array}$} \\
\hline 1. Preconsumer production scrap and residues & Increasing \\
\hline $\begin{array}{l}\text { REE containing residues arising } \\
\text { during metal production/recycling }\end{array}$ & All REEs \\
\hline $\begin{array}{l}\text { Postsmelter and Electric Arc } \\
\text { Furnace residues }\end{array}$ & Ce, La, critical REEs & $\begin{array}{l}\text { Future levels depend on End- } \\
\text { of-Life presmelter recycling }\end{array}$ \\
\hline $\begin{array}{l}\text { Industrial residues } \\
\text { (phosphogypsum, red mud, etc.) }\end{array}$ & All REEs & Relatively stable \\
\hline 2. End-of-Life products containing & $\begin{array}{l}\text { Eu, Tb, Y (Ce, Gd, } \\
\text { La) }\end{array}$ & \\
\hline Phosphors & $\begin{array}{l}\text { Eu, Tb, Y (Ce, Gd, } \\
\text { La) }\end{array}$ & Relatively stable \\
\hline Fluorescent lamps (straight/curved & \begin{tabular}{l} 
Increasing \\
\hline Compact fluorescent lamps (CFLs)
\end{tabular} & La) \\
\hline LEDs (Ce, Gd, & Ce, Y & Increasing \\
\hline LCD Backlights & $\begin{array}{l}\text { Eu, Tb, Y (Ce, Gd, } \\
\text { La) }\end{array}$ & Relatively stable \\
\hline Plasma Screens & Eu, Tb, Y (Ce, Gd, La) & Relatively stable \\
\hline Cathode-ray tubes (CRTs) & Eu, Y & Sharply decreasing \\
\hline $\begin{array}{l}\text { CRT phosphors, fluid, glass } \\
\text { polishing powders, optical } \\
\text { glass, cracking catalysts, }\end{array}$ & All REEs & Depending on a residue type \\
\hline 3. Landfilled REEs containing residues \\
\hline $\begin{array}{l}\text { Industrial residues } \\
\text { (phosphogypsum, red mud, etc.) }\end{array}$ & All REEs & \\
\hline
\end{tabular}

One of the major challenges in the processing of used phoshors for the extraction of rare earths lies in a large number of different compounds and their individual chemical properties such as solubility in an aqueous phase (Poscher, 2013, pp.1217-1222). The summary of this 
work showed that the hydrochloric leaching of a screened luminophore powder followed by the precipitation of a contaminated RE oxalate, converting the mixture into their oxides and subsequent raffination in order to dissolve most of the alkali metal oxides leads to a RE concentrate which could be applied as a new raw material for the subsequent process steps of refining.

The dissolution of non-ferrous metals from ores into a solution during high pressure leaching in an autoclave was described in detail (Author, 2011, pp.29-44.) for some nonferrous metals such as nickel and cobalt. A hydrometallurgical treatment has a lot of advantages compared to a pyrometallurgical treatment.

In this work, a dissolution of yttrium from waste ceramic dust under atmospheric and high pressure was studied in detail. The influence of different process parameters such as leaching temperature and time, concentration of hydrochloric acid and operating pressure was analyzed. The main aim is to study the kinetics of yttrium dissolution with hydrochloric acid in the temperature range from $20^{\circ} \mathrm{C}$ to $70^{\circ} \mathrm{C}$ at atmospheric pressure.

\section{Experimental Work}

Material

Ceramic materials remain from a knock-off of cast parts containing a high amount (up to $15 \%$ ) of yttrium oxide from the upper layers of shells. The elements such as titanium, aluminium, and iron are regarded as impurities in these waste materials.

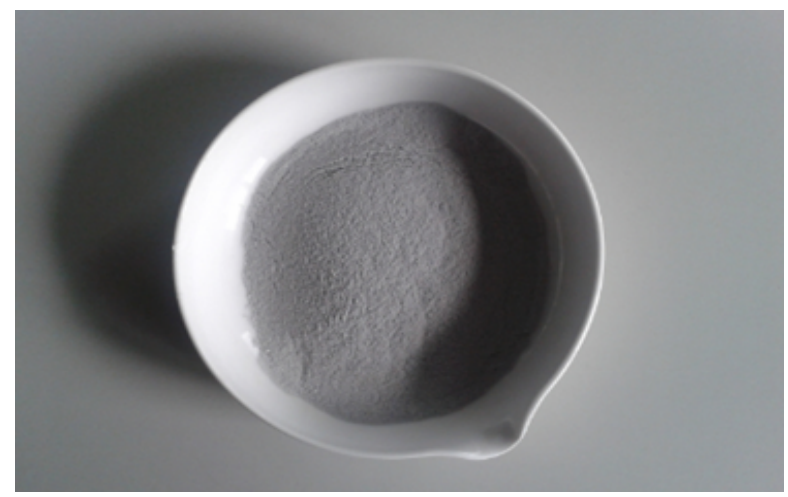

Figure 2 - The waste ceramic dust Puc. 2 - Отходная керамическая пыль Slika 2 - Otpadni keramički prah 
The chemical composition of the waste ceramic dust studied in this work amounts to (in \%): $1.34 \mathrm{Y} ; 0.56 \mathrm{Fe}_{2} \mathrm{O}_{3}, 0.5 \mathrm{TiO}_{2} ; 0.48 \mathrm{SiO}_{2}$; and $97.12 \mathrm{Al}_{2} \mathrm{O}_{3}$. This fine dust fraction was approx. below $250 \mu \mathrm{m}$.

\section{Experimental Procedure}

Leaching tests were performed under a) atmospheric pressure in a glass reactor at $20^{\circ} \mathrm{C}, 45^{\circ} \mathrm{C}$ and $70^{\circ} \mathrm{C}$ and b) high pressure in an autoclave at $150^{\circ} \mathrm{C}$ (pressure about $5 \times 10^{5} \mathrm{~Pa}$ ) using hydrochloric acid. The temperature was controlled within $\pm 1{ }^{\circ} \mathrm{C}$ by a temperature control system which controlled a water cooling system as well (see Figure 3 ).
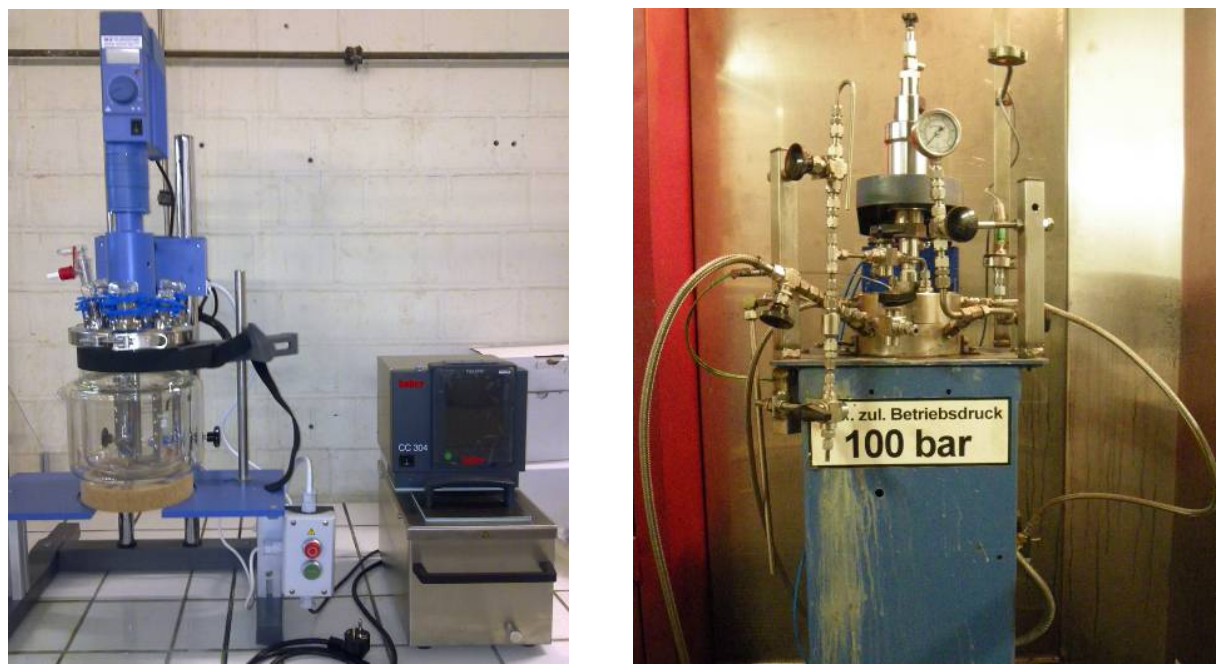

Figure $3-$ a) a glass reactor b) an autoclave

Puc. 3 - a) стеклянный реактор б) автоклав

Slika 3 - a) stakleni reaktor b) autoklav

Agitation was provided by a motor-driven impeller. A certain amount of waste dust was mixed with a pre-calculated amount of deionised water. The slurry was then heated up to a predetermined temperature under continuous agitation. Upon temperature stabilisation, a certain amount of different concentration of hydrochloric acid was injected into the reactor under atmospheric and high pressure. Using the sampling system, $20 \mathrm{ml}$ of liquid was periodically withdrawn through a dip tube and then rapidly cooled. After the end of the experiments, the solutions aliquots were filtered and analysed, aiming at $\mathrm{Y}, \mathrm{Fe}, \mathrm{Al}$ and $\mathrm{Ti}$ by inductively coupled plasma ICP spectrophotometry and X-ray fluoroscency. 


\section{Results}

The influence of different experimental parameters such us the leaching time, the leaching temperature and the concentration of hydrochloric acid on yttrium dissolution were investigated. The obtained results between $20^{\circ} \mathrm{C}$ and $150^{\circ} \mathrm{C}$ were shown in Figure 4 and Figure 5:

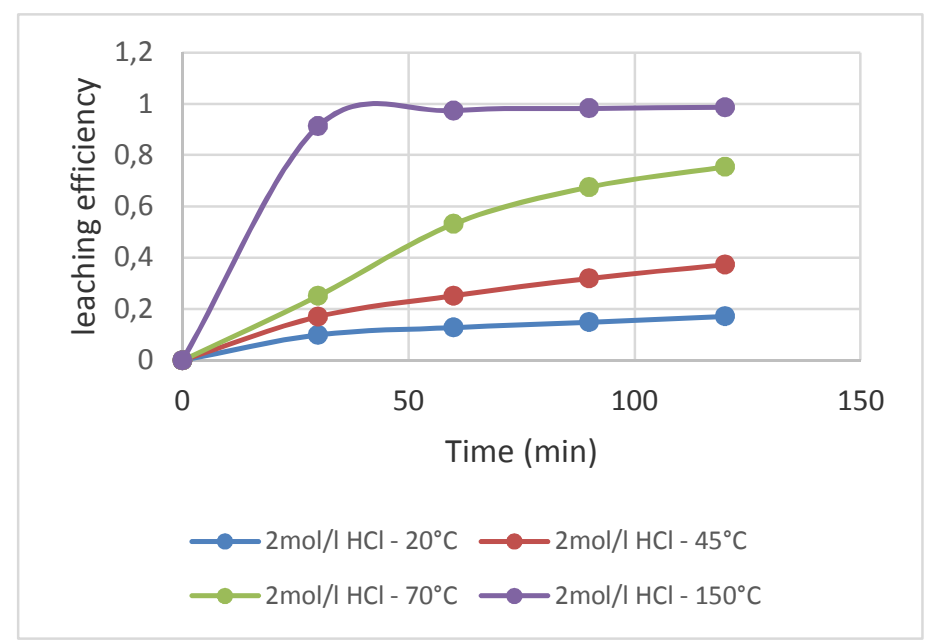

Figure 4 - Influence of temperature and time on the yttrium dissolution

Puc. 4 - Влияние температуры и времени на процесс растворение иттрия Sliika 4 -Uticaj temperature i vremena na rastvaranje itrijuma

The minimum efficiency of yttrium dissolution is found at room temperature. An increase of leaching time to $120 \mathrm{~min}$ and temperature from $20^{\circ} \mathrm{C}$ to $150^{\circ} \mathrm{C}$ using $2 \mathrm{M} \mathrm{HCl}$ solution leads to an increased leaching efficiency of yttrium up to $98.6 \%$. At $70^{\circ} \mathrm{C}$ and under atmospheric pressure, the leaching efficiency amounts to about $80 \%$ in $120 \mathrm{~min}$. An increase of the concentration of hydrochloric acid from $0.5 \mathrm{~mol} / \mathrm{L}$ to $2.0 \mathrm{~mol} / \mathrm{L}$ leads to an increased yttrium dissolution efficiency. 


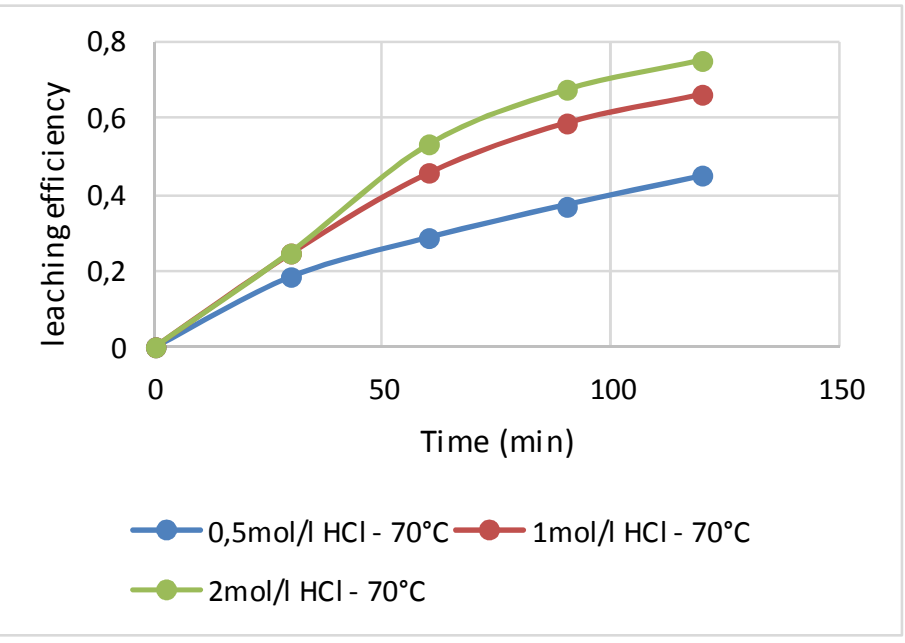

Figure 5 - Influence of the concentration of hydrochloric acid on yttrium dissolution Puc. 5- Влияние концентрации соляной кислоты на процесс растворения иттрия Slika 5 - Uticaj koncentracije hlorovodonične kiseline na rastvaranje itrijuma

Under the same conditions, the dissolution of iron with hydrochloric acid is very high at $70^{\circ} \mathrm{C}$ for all used concentrations.

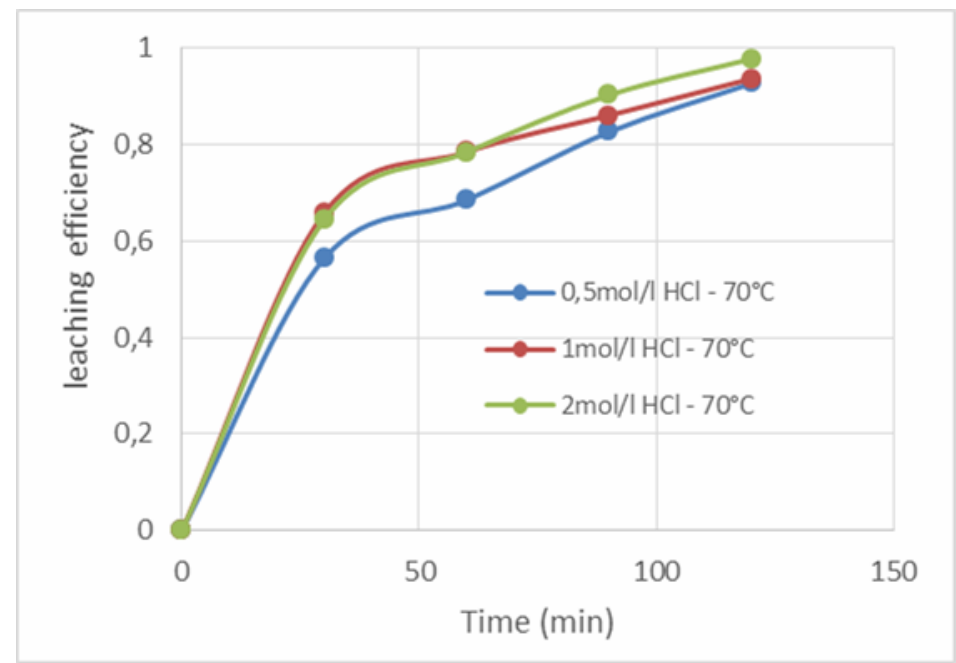

Figure 6 - Influence of the concentration of hydrochloric acid on iron dissolution at $70^{\circ} \mathrm{C}$ Puc. 6 - Влияние концентрации соляной кислоты на процесс растворения железа при температуре выше $70^{\circ} \mathrm{C}$

Slika 6 - Uticaj koncentracije hlorovodonične kiseline na rastvaranje gvožđa na temperaturi od $70^{\circ} \mathrm{C}$ 
We assumed that the chemical reaction at the phase boundary solidliquid is the limiting step. The solid phase is yttrium oxide on aluminium oxide as a matrix. Therefore, a kinetic analysis of the dissolution process of waste dust was performed using the next mathematical model.

$$
1-(1-X)^{1 / 3}=k t
$$

\section{Where:}

$X$ - Leaching efficiency of yttrium dissolution (between 0 and 1 )

$\mathrm{k}$ - Rate constant, $\mathrm{min}^{-1}$

$\mathrm{t}$ - Leaching time (min).

A graphical representation of the experimental data of the leaching processes in the coordinate system which corresponds to the chemical rate control for spherical particles is shown in Figure 7:

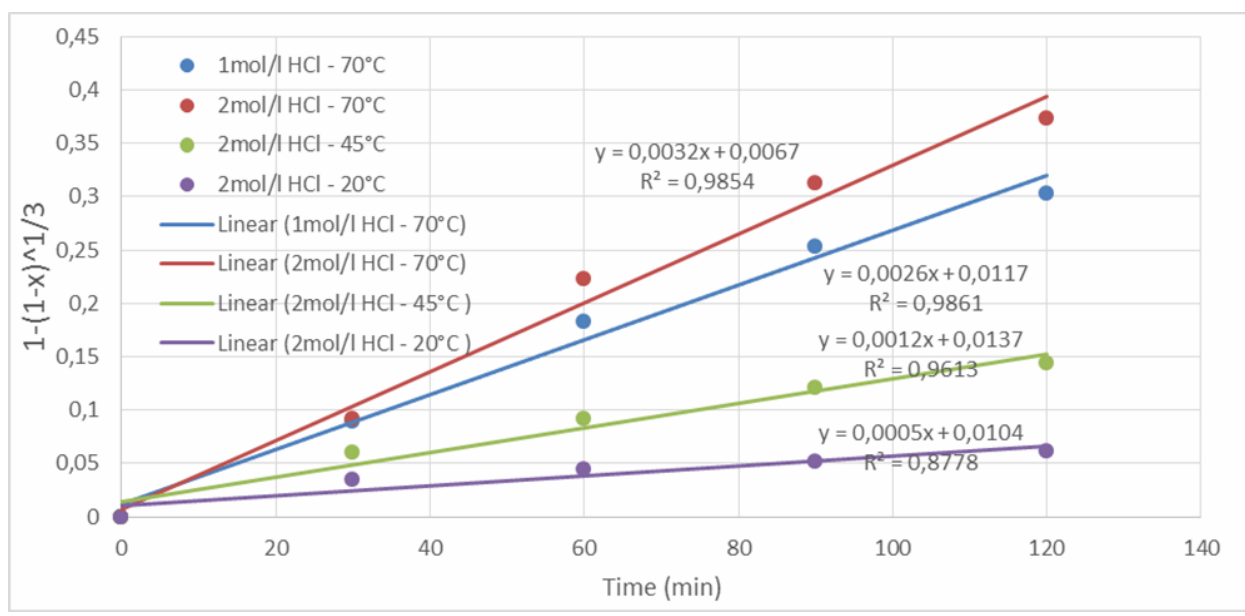

Figure 7 - Testing of kinetic model for dissolution of yttrium Puc. 7 - Тест кинетической модели растворения иттрия Slika 7 - Ispitivanje kinetičkog modela rastvaranja itrijuma

Good linearization exists for all three investigated temperatures. In all three cases, at $20^{\circ} \mathrm{C}, 45^{\circ} \mathrm{C}$ and $70^{\circ} \mathrm{C}$, the straight lines begin from the origin of the coordinate system. The slopes of these lines correspond to the rate constants of the corresponding reactions of yttrium dissolution in hydrochloric acid (Eq. 2).

$$
\mathrm{Y}_{2} \mathrm{O}_{3}+6 \mathrm{HCl}=2 \mathrm{Y}^{3+}{ }_{(\mathrm{aq})}+6 \mathrm{Cl}_{(\mathrm{aq})}^{-}+3 \mathrm{H}_{2} \mathrm{O}
$$


The reaction rate constants for yttrium dissolution at different temperatures were graphically determined:

$$
\begin{aligned}
& \mathrm{k}_{70^{\circ} \mathrm{C}}=\tan (0,0032)=5,585^{*} 10^{-5} \mathrm{~min}^{-1} \\
& \mathrm{k}_{45^{\circ} \mathrm{C}}=\tan (0,0012)=2,0944^{*} 10^{*} 10^{-5} \mathrm{~min}^{-1} \\
& \mathrm{k}_{20}{ }^{\circ} \mathrm{C}=\tan (0,0005)=8,7266^{*} 10^{*} 10^{-6} \mathrm{~min}^{-1}
\end{aligned}
$$

The statement on the rate-limiting step was further investigated using the Arrhenius plot.

$$
k=k_{o} \cdot \exp \left(-E_{A} / R T\right)
$$

If in $k$ over $1000 / T$ is applied, the apparent activation energy $E_{A}$ can be determined (as shown in Figure 8).

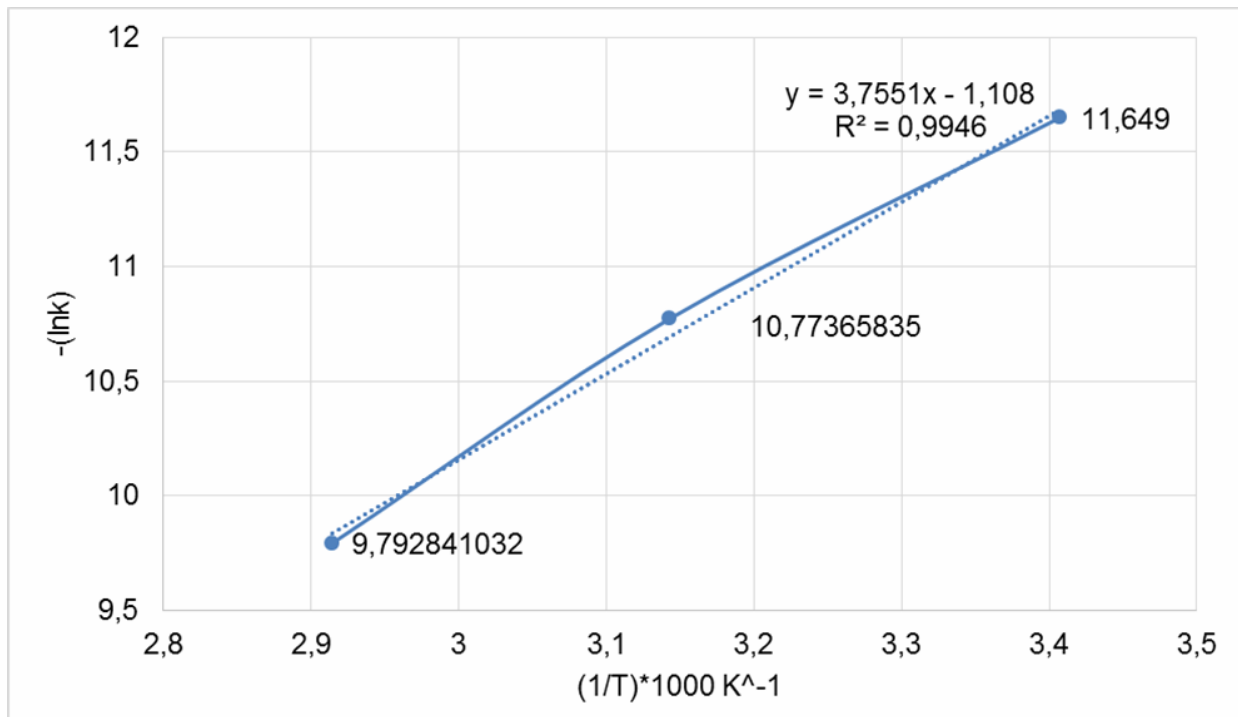

Figure 8 - Arrhenius plot for the dissolution of yttrium with hydrochloric acid between $20^{\circ} \mathrm{C}$ and $70^{\circ} \mathrm{C}$

Puc. 8 - График уравнения Аррениуса для растворения иттрия в соляной кислотойе при температуре $20^{\circ} \mathrm{C}-70^{\circ} \mathrm{C}$

Slika 8 - Grafički prikaz Arenijusove jednačine rastvaranja itrijuma u hlorovodoničnoj kiselini na temperaturi između $20^{\circ} \mathrm{C} \mathrm{i} 70^{\circ} \mathrm{C}$

The calculated activation energy amounts to $31.2 \mathrm{~kJ} / \mathrm{mol}$. The dissolution of yttrium as yttrium oxide with hydrochloric acid from aluminum oxide as matrix depends on a reaction at the solid-liquid phase. 


\section{Conclusions}

The present study summarized the influence of different reaction parameters such as leaching temperature, time and concentration of hydrochloric acid on yttrium dissolution from waste ceramic dust. An increase of dissolution time and temperature increases yttrium dissolution. The maximal yttrium dissolution efficiency was obtained using $2 \mathrm{M} \mathrm{HCl}$ at atmospheric pressure at $70^{\circ} \mathrm{C}$ (about $80 \%$ ). An increase of pressure from atmospheric pressure to $0.5 \mathrm{MPA}$ at $150^{\circ} \mathrm{C}$ leads to the maximum dissolution of yttrium (about $98.6 \%$ ). A kinetic analysis revealed that the dissolution of yttrium with hydrochloric acid can be described using a kinetic model based on the reaction at the solid-liquid phase as a limiting step. The calculated activation energy $\mathrm{E}_{\mathrm{A}}$ between $20^{\circ} \mathrm{C}$ and $70^{\circ} \mathrm{C}$ amounts to $31.2 \mathrm{~kJ} / \mathrm{mol}$. The selectivity of the dissolution process regarding the presence of iron will be studied in our future work. Precipitation and solvent extraction will be used in particular for a production of a cleaned solution based on yttrium chloride.

\section{References}

Amaral, J., \& Morais, C. 2010. Thorium and uranium extraction from rare earth elements in monazite sulfuric acid liquor through solvent extraction. Minerals Engineering, 23, pp.498-503.

Binnemans, K., Jones, P.T., Blanpain, B., van Gerven, T., Yang, Y., Walton, A., \& Buchert, M. 2013. First comprehensive review paper on rare-earth recycling: Recycling of rare earths: A critical review. Journal of Cleaner Production, 51, pp.1-22.

Ibrahim, T., \& El-Hussaini, 2007. Production of anydrite-gypsum and recobvery of rare earths as a by-product.Hydrometallurgy, 87, pp.11-17.

Kim, E., \& Osseo-Asare, K. 2012. Aqueous stability of thorium and rare earth elements in monazite hydrometallurgy.Hydrometallurgy, 113-114, pp.67-78.

Kuzmin, V., \& et al., 2012. Combined approaches for comprehensive processing of rare earth metal ores. Hydrometallurgy, 129-130, pp.1-6.

Mackowski, S.J., \& et al., 2009. Recovery of Rare earth elements, US Patent 0272230 A1.

Poscher, Luidold, A., Kaindl, S., \& Antrekowitsch, M. 2013. Recycling of rare earth from spent phosphors. . In: Proceeding of EMC Conference. , pp.1217-1222

Stopić, S., \& Friedrich, B. 2011. Pressure hydrometallurgy: A new chance to nonpolluting processes. Vojnotehnički glasnik/Military Technical Courier, 59(3), pp.29-44.

Sung-Don, K., Jin-Young, L., Chul-Joo, K., Ho-Sung, Y., \& Joon-Soo, K. 2010. $\mathrm{NaOH}$ Decomposition and Hydrochloric acid leaching by hot digestion method. Journal of the Korean Institute of Resources Recycling, 19(6), pp.70-76. 


\section{КИНЕТИКА РАСТВОРЕНИЯ ИТТРИЯ ИЗ ОТХОДНОЙ КЕРАМИЧЕСКОЙ ПЫЛИ}

\section{Сречко Р. Стопич, Бернд Г. Фриедрих}

Технический университет города Ахен, Институт металлургических процессов и рециклирования металлов, Германия

ОБЛАСТЬ: химические технологии

ВИД СТАТЬИ: оригинальная научная статья

ЯЗЫК СТАТЬИ: английский

\section{Резюме:}

Иттрий светло-серебристый редкоземельный металл побочной группы, обладающий аналогичными лантатдоиду химическими свойствами.

Иттрий и оксид иттрия используются в производстве люминесцеентных ламп, электродов, электронных фрильтров, сверхпроводников и в качестве укрепляющих добавок к различным материалам.

Большая часть иттрия извлекается из его минералов, таких как монациты [(Ce, La, Th, Nd, Y)PO $\mathrm{PO}_{4}$ и ксенотимы $\mathrm{YPO}_{4}$

Наличие радиоактивных элементов тория и урана, а также иттрия усложняет процесс получения оксида иттрия из руд и концентратов.

Так как стандарты по охране окружающей среды с каждым днем повышаются, извлечение данных элементов становится рискованным.

Поэтому рециклирование оксида иттрия из вторичных ресурсов, таких как: красный шлам, покрытие для керамики и использованные материалы в производстве люминесцентных ламп имеет большое значение.

Основной целью данной работы является изучение кинетики растворения иттрия с соляной кислотой из отходной керамической пыли.

Ключевые слова: иттрий, рециклирование, гидрометаллургия, керамика.

\section{KINETIKA RASTVARANJA ITRIJUMA IZ OTPADNOG KERAMIČKOG PRAHA}

Srećko R. Stopić, Bernd G. Friedrih

Tehnički Univerzitet u Ahenu, Institut za procesnu metalurgiju

i recikliranje metala, Nemačka

OBLAST: hemijske tehnologije

VRSTA ČLANKA: originalni naučni članak

JEZIK ČLANKA: engleski 
Sažetak:

Itrijum je srebrnasti prelazni metal sa hemijskim svojstvima sličnim lantanoidima. Zbog ovih sličnosti itrijum pripada elementima retkih zemalja. Itrijum i itrijumoksid koriste se u fluoroscentnim lampama, u proizvodnji elektroda, u elektronskim filterima, superprovodnicima i kao dodatak u različitim materijalima radi poboljšanja njihove stabilnosti. Veliki deo itrijuma dobijen je iz njegovih minerala kao što su monazit $\left[(\mathrm{Ce}, \mathrm{La}, \mathrm{Th}, \mathrm{Nd}, \mathrm{Y}) \mathrm{PO}_{4}\right]$ i ksenotim $\mathrm{YPO}_{4}$. Prisustvo radioaktivnih elemenata torijuma i urana, zajedno sa itrijumom, predstavlja teškoću u dobijanju itrijumoksida iz ruda $i$ koncentrata. Regulisanje zaštite životne sredine je sve strože i povećava rizik u njihovom snabdevanju. Zbog svega toga recikliranje itrijumoksida iz sekundarnih izvora, kao što su crveni mulj, prevlake u keramici $i$ istrošeni materijali u fluoroscentnim lampama, ima veliki značaj. Osnovni cilj ovog rada jeste da prouči kinetiku rastvaranja itrijuma sa hlorovodoničnom kiselinom iz otpadnog praha keramičkih materijala.

Ključne reči: itrijum, recikliranje, hidrometalurgija, keramika.

Datum prijema članka / Дата получения работы / Paper received on: 05. 07. 2015.

Datum dostavljanja ispravki rukopisa / Дата получения исправленной версии работы / Manuscript corrections submitted on: 20. 10. 2015.

Datum konačnog prihvatanja članka za objavljivanje / Дата окончательного согласования работы Paper accepted for publishing on: 22. 10. 2015.

(C) 2016 Autori. Objavio Vojnotehnički glasnik / Military Technical Courier (www.vtg.mod.gov.rs, втг.мо.упр.срб). Ovo je članak otvorenog pristupa i distribuira se u skladu sa Creative Commons licencom (http://creativecommons.org/licenses/by/3.0/rs/).

(c) 2016 Автор. Опубликовано в "Военно-технический вестник / Vojnotehnički glasnik / Military Technical Courier" (www.vtg.mod.gov.rs, втг.мо.упр.срб). Данная статья в открытом доступе и распространяется в соответствии с лицензией "Creative Commons" (http://creativecommons.org/licenses/by/3.0/rs/).

(c) 2016 The Authors. Published by Vojnotehnički glasnik / Military Technical Courier (www.vtg.mod.gov.rs, втг.мо.упр.срб). This article is an open access article distributed under the terms and conditions of the Creative Commons Attribution license (http://creativecommons.org/licenses/by/3.0/rs/). 